\title{
A VALÓSZÍNŨSÉGSZÁMÍTÁS KÖZGAZDASÁGI INTERPRETÁCIÓJÁRÓL
}

Medvegyev Péter ${ }^{1}$

A dolgozat a közgazdasági modellezés matematikai hátterének problémáit vizsgálja. A modellezés legfőbb problémája, hogy a vizsgált jelenségek nem emelhetők ki a környezetükből, és nem lehet egyszerüsített modellel a gazdasági jelenségeket leírni, következésképpen a világ lényegében megismerhetetlen, és ez a megismerhetetlenség a bizonytalanság legfőbb oka. A kockázat fogalma már bizonyos megismerhetőséget feltételez, ami a gazdasági rendszerekben nem adott.

JEL-kódok: A12, B16, Co, G17

Kulcsszavak: valószínűség, előrejelezhetőség, deriválhatóság, közgazdasági modellezés matematikai háttere

A valószínűségszámítás, illetve a valószínűség közgazdasági interpretációja többször is felmerült, és egyfajta örökzöld témának tekinthető. Száz Jánosnak a jelen lapszámban megjelent véleményével ${ }^{2}$ teljesen egyetértve, érdemes abból kiindulni: a probléma bonyolultsága nagyrészt abból ered, hogy több egymáshoz nem tartozó kérdést egyidejüleg akarunk megmagyarázni.

Elsőként érdemes a származtatott termékek árazását leválasztani, ugyanis - bár ez a sztochasztikus analízis közgazdasági alkalmazásának zászlóshajója -, valójában az elméletnek semmi köze a véletlenhez. Vagy csak formálisan tűnik úgy, hogy egyfajta véletlenhez kapcsolódó kérdésről van szó. A származtatott termékek árazásának központi gondolata a fedezés. Egy származtatott termék ára annyi, amennyibe a terméket fedező önfinanszírozó portfólió kerül. Ha nincs fedező portfólió, márpedig ilyen általában nincs, akkor az elmélet nem tud választ adni a feltett kérdésre. Marad a jó öreg kereslet-kínálat elmélete. Nem lehet ezt eléggé hangsúlyozni. Nincs itt semmi bonyolultság. Az árakat a kereslet és a kínálat határozza meg. Egy nagyon speciális és a valóságban tán soha elő nem forduló helyzetben, amikor a származtatott termék fedezhető, a kereslet és a kínálat független a preferenciáktól, és ilyenkor az ár egyszerűen felírható. A kérdés

$1 \quad$ Medvegyev Péter egyetemi tanár, Budapesti Corvinus Egyetem. E-mail: medvegyev@unicorvinus.hu.

2 SzÁz JÁNos (2020): Keynes és a valószínűség értelmezése vs. a valószínűségszámítás felhasználása az opcióárazásban. Gazdaság és Pénzügy 7(2), 150-160. 
tehát az, hogy van-e önfinanszírozó fedező portfólió. Ez másképpen azt jelenti, hogy egy nagyon bonyolult matematikai szituációban meg tudunk-e oldani egy lineáris egyenletrendszert vagy sem. Ilyen értelemben a kérdésnek sokkal inkább a lineáris algebra, illetve a lineáris programozás a háttere, csak a történet nem egy véges dimenziós térben, hanem egy végtelen dimenziós térben játszódik. Vagyis a matematikai köntös, amely a tartalmat eltakarja, igen impozáns, de mégis csupán egy köntös. A származtatott termékek árazása a jó öreg általános egyensúlyelmélet egy fejezete, az árak pedig a termelési halmazhoz tartozó duális változók. A nehézség abból ered, hogy a tér, ahol az egyenletrendszert meg kell oldani, végtelen dimenziós. Ezenkívül még nem is egyszerű a struktúrája, ugyanis nemcsak az egyes kimenetelek száma végtelen, hanem az egyes időpontok száma is. Vagyis, ha úgy tetszik, a probléma többszörösen is végtelen. Amennyiben a két végtelentől megszabadulunk, a probléma felfedi valós jellegét, és kiderül, hogy például a lineáris programozás dualitási tételéből az eszközárazás mindkét tétele levezethető. Ha csak az időhorizontot tekintjük végesnek, de a kimenetelek számát meghagyjuk végtelennek, akkor a tárgyalás az általános esethez képest jóval egyszerübbé válik, és egyértelmüen kiderül, hogy a konvex halmazok elválasztási tételét kell alkalmazni. Más oldalról persze, ha az időhorizontot és a kimeneteleket is végtelennek tekintjük, akkor a felmerülő matematikai problémák olyan tömege zúdul ránk, amelyet csak a legfelkészültebbek tudnak kezelni.

Tovább bonyolítja a helyzetet, hogy lényegében a legegyszerűbb esetben, amikor az eszközárak egy geometriai Wiener-folyamat szerint alakulnak, az úgynevezett Girszanov-tétel egy egyszerűsített utat jelent. A Girszanov-tétel persze nem egy nagyon egyszerü tétel, de jóval egyszerübb, mint az általános esetben alkalmazott eszköztár, és a Girszanov-tétel által jelzett mértékcsere azt a benyomást kelti, mintha egyfajta szubjektív valószínűség mellett kellene a kimeneteleket kiértékelni, és a származtatott termékek ára a kockázatmentes világban vett várható értékkel árazható. Miközben az új valószínűségek egyszerüen duál változók, vagyis, ha úgy tetszik, a lineáris programozás árnyékárai.

A származtatott termékek árazásának problémáját elhagyva, a kérdés nagyon egyszerű: megismerhető-e világ? A kérdéssel, bár jogos, egy nagy baj van. A benne szereplő két fogalom, a „megismerhető” és a „világ” fogalmak egyike sincsen definiálva, így a kérdésre nem tudunk választ adni. A kérdés a közgazdaságtanban különösen élesen jelentkezik, ugyanis már annak a meghatározása, hogy mégis hol húzódnak a határok - mikor beszélünk társadalmi kérdésről vagy politikai kérdésről, és mikor beszélünk gazdasági kérdésről -, igencsak esetleges. A közgazdasági viták és csatározások nagyrészt a terület kijelölése körül forognak: mi tartozik bele, mi nem. A „Mi a közgazdaságtan?” címü vita mindig aktuális és mindig éles. A vita mögött pedig az húzódik meg, hogy már magának a vizsgálat tárgyának a kijelölése is igencsak esetleges. A valószínűség kérdése 
nagyrészt a megismerhetőség kérdéséhez tartozik. Ha tudjuk az egyes lehetőségek jövőbeli kimeneteleinek a valószínűségét, akkor valamit megismertünk, ha mást nem, hát a valószínűségeket és a lehetséges kimeneteleket. Természetesen a fö probléma az, hogy elöször a határokat kell meghúzni - ha úgy tetszik, a misztikus nagy Omega-halmazt kell meghatározni. Mivel a közgazdaságtan a határok kijelölésében is bizonytalan, nem túl meglepő, hogy valószínüségek kijelölésében még inkább bizonytalan. És ettől a ponttól kezdve a kérdés teljesen áttekinthetetlenné és nyugodtan mondhatjuk, zavarossá válik. Érdemes ismételten és nyomatékosan hangsúlyozni, hogy a gazdasági folyamatok előrejelezhetősége nagyrészt attól függ, hogy miként tudjuk a problémát lokalizálni. Egy jól körülírható rendszerben, ahol kevés és jól meghatározott számú változó van, az előrejelezhetőség megoldható. Hogy a címben szereplő kérdésre utaljak: egy rosszul körülhatárolt rendszerben nehéz a statisztika és a valószínüségszámítás alapfeltételét, a független és azonos eloszlású, nagy elemű minta követelményét biztosítani. Másképpen formailag úgy jelentkezik a kérdés, hogy nem tudjuk alkalmazni a valószínűségszámítást. Ugyanakkor a probléma nem a valószínűségszámításból vagy a statisztika frekvencionista interpretációjából adódik, hanem a vizsgált jelenség jellegéből fakad. Ami persze azt is jelenti, hogy más módszerekkel sem lehet pontos elörejelzéseket adni. Talán nem érdektelen megemlíteni, hogy a fizikai elméletek közül az egyik, ha nem a legimpozánsabb, az elektromosságtan. Hogy mennyire impozáns az elmélet és a felhalmozott tudás, ahhoz elég, ha valaki ránéz a telefonjára. Ugyanakkor egy olyan nyilvánvalónak tűnő kérdésre, hogy miért és hogyan keletkeznek a villámok, nincs megnyugtató és meggyőző elmélet. ${ }^{3}$

Természetesen a tudományos közösség próbál ezen a helyzeten segíteni, és modelleket épít, vagyis mesterségesen kijelöl bizonyos kérdéseket, és ezeket kezdi vizsgálni, majd a modell tulajdonságainak vizsgálatát azonosítja a modellezés tárgyának vizsgálatával. Továbbá, mint minden emberi tevékenység, ez is társadalmi jelenség, ha úgy tetszik, a megélhetésről és a pénzről szól, és a dolog, a

3 Feynman et al. (1986): Mai fizika. 5. kötet. Budapest: Műszaki Könyvkiadó, 133. o. Persze a hivatkozott irodalom nem a legújabb, és nem is állítom, hogy a terület szakértője vagyok, így elképzelhető, hogy azóta a kérdés megnyugtatóan tisztázódott. Ugyanakkor érdemes hangsúlyozni, hogy miközben ellenőrzött körülmények között mind matematikailag, mind gyakorlati mérnöki szinten is páratlan ismeretekkel rendelkeznek a területen dolgozó kutatók, amennyiben a kérdés nem kontrollált körülmények között, a maga természetes voltában jelenik meg, mindjárt nem olyan világos, hogy mit kell tenni, és mi miért olyan, amilyen. A közgazdaságtan problémái abból erednek, hogy nincsenek kontrollált körülmények, a dolog jellege miatt értelmes módon nem lehet egy egyedet például a társadalmi környezetéből kiszakítani vagy valamely jelenséget a környezetétől izolálni. Hallgatókoromban elég nevetségesnek tartottam, amikor minden kérdésre azt kellett válaszolni, hogy társadalmi viszony. Például mi az ár, mi a kereslet stb. Ma úgy gondolom, hogy ez egy igen bölcs, bár nyilván nem nagyon előremutató észrevétel volt. 
modell, elkezd önálló életre kelni. A pénzért, a befolyásért, a címekért folyó örök harc a kutatókat csapatokba rendezi, és ezeket a csapatokat, kutatói közösségeket a közös érdek legalább annyira összetartja, mint a kutatás tárgyának megismerhetősége. Nyilván teljesen abszurd modelleket nem lehet a végtelenségig hirdetni, bár aki keres, az talál, bármennyire erős is a csapatérdek. Egy másik csapat érdeke azt diktálja, hogy a gyengébb modell körül állók helyébe lépjen. Ezért mindent meg is tesz. Vagyis a tudományos életben, miként a társadalom minden területén, a harc az erőforrásokért a hatékonyság irányába mozdítja el a rendszert. Az, hogy ez milyen sebességgel folyik, egy másik kérdés. Általában az egyes harcoló csapatok azonos korosztályhoz tartoznak, vagyis az elörejutás sebessége nem túl nagy, nem beszélve arról: semmi garancia nincsen arra, hogy a fiatalabb generáció elörelép, és nem visszafelé.

A modell és a valóság viszonyára érdemes egy némiképpen elvont példát meggondolni. A példa előnye, hogy igen konkrét és jól definiált. A kérdés a következő: miként tudjuk a Poisson-folyamatot számítógéppel szimulálni? A Poisson-folyamat a matematikai világban jól definiált fogalom. Ha úgy tetszik, a matematikai világban objektíven létezik. Ha azonban számítógéppel akarjuk szimulálni, egy alapvető kérdéssel szembesülünk: a két rendszer mást ért számon. A matematikai világban a számon valós számot értünk, és a valós számok axiómáit az analíziselőadások elején az érdeklődő hallgatóság elé tárja a lelkes oktató. Ugyanakkor a számítógépek világában valami egészen mást értenek valós számon. Nyilván a számítógépes valós szám fogalma a lehetőségekhez képest a lehető leginkább közelíteni akarja a valós szám matematikai fogalmát. De az is nyilvánvaló, hogy a lehetőségek ezt erősen korlátozzák. Ennek megfelelően az idő fogalma a két rendszerben teljesen más. A számítógépes Poisson-folyamat minden tekintetben más lesz, mint a valós, matematikai Poisson-folyamat. A Poisson-folyamat kritikus tulajdonságainak levezetésekor a végletekig ki kell használni a valós számok matematikai tulajdonságait. A valós, matematikai Poisson-folyamat mely tulajdonságai fontosak, és mely tulajdonságoktól tudunk eltekinteni? További probléma, hogy bár sok tulajdonságot tudunk esetleg szimulálni, ennek ára van, amit időben, tárhelyben ki kell fizetni. Vagyis csak bizonyos korlátok és bizonyos célok együttes mérlegelése után tudunk a szimulálás mikéntjéről dönteni.

És akkor mi van a Poisson-folyamat alkalmazásával mondjuk az Auchan kasszáinál? A Poisson-folyamat számos alkalmazással rendelkezik a sorban állási rendszerek elméletében. Milyen időfogalommal dolgozik az egyszerű vásárló, és az miként viszonyul a valós számok matematikai axiómáihoz? A kiszolgálási rendszerekben a várakozási idő tényleg exponenciális? Vagy csak hasonlít rá? Vagy csak rámondjuk, hogy olyan, mert nem tudunk jobbat kitalálni? Vagy ha tudunk is, nem érdemes, mert így is, úgy is rosszul méretezzük a rendszert, és a legegyszerübb, ha a legendás Józsi bácsira bízzuk a tervezést? Mennyire lehet és mennyire 
érdemes ezt a kérdést feszegetni? Hol az a pont, amikor be kell látni, hogy a tükör, amelyben nézzük a világot, esetleges, hamis és torz? Nem beszélve arról, hogy nem is a világot nézzük, hanem egy másik tükör által elénk vetített mozifilmet.

Ma már szinte senki és szinte sehol nem találkozik a valósággal, hanem csak annak sokszoros áttételen való tükröződéseit látja. A tükröződés oly sokszoros, hogy teljes joggal felvethetjük: talán a valóság nem is létezik, vagy ha létezik is, számunkra felismerhetetlen. A „mi a valószínűség, annak mi a helyes közgazdasági interpretációja" sajnos álprobléma. Nincs helyes, csak célszerű és hasznos interpretáció. Hogy mi a célszerü, és mi a hasznos? Ez is egy jó kérdés. A válasz csak bonyolult társadalmi összefüggéseiben értelmezhető. Sokszor a hasznos az, hogy lehet-e belöle cikket írni, és növelni lehet-e vele az idézetek számát. Néha az, hogy sikerül-e egy jó tőzsdei startégiát felépíteni. Az ember, miként mondani szokás, eszközépítő állat. Az eszközöket a túlélés elősegítésére építi. A nagy változás, ami a 19. század óta a szellemi eszközépítésben megtörtént, az, hogy egyre kevésbé, vagy inkább egyáltalán nem azért építjük a szellemi eszközeinket, hogy megismerjük az isten által teremtett világot. Sajnos, tudomásul kell venni, hogy a nagy felfedezések korának vége. Tudom, ezt gondolták a 19. század végén is, majd jött a 20. század, és a tudomány világában minden a feje tetejére állt. De ami egyszer igaz volt, miért lenne mindig igaz? Volt már erre is meg amarra is példa.

A közgazdaságtan alapvetően nem a valószínűségek ilyen vagy olyan jellege miatt nem képes a jövőt előre jelezni. Nem a valószínűségszámítás ilyen vagy olyan interpretációja a probléma. A legfőbb probléma az, hogy az említett tudományág a saját tárgyát nem képes egyértelműen kijelölni, nem tudja leválasztani, hogy mi az, amit vizsgál és mi az, amit nem vizsgál. Ha úgy tetszik, nincsenek rögzített paraméterek, minden érték változó. Nem a kutatók felkészültségével vagy az alkalmazott módszerek nem megfelelö voltával van a gond, hanem avval, hogy a vizsgálat tárgya nem emelhető ki a környezetéből, illetve a környezet nem alakítható megfelelően. Az úgynevezett elméleti közgazdaságtan megpróbálja a sikeres tudományok módszertanát majmolni, miközben az ott felhasznált eszközök számára idegenek. Görcsösen kapaszkodik abba az illúzióba, hogy képes magyarázatot adni a gazdasági folyamatok alakulására, miközben azt sem tudja megmondani, hogy mit mér, mi az a jelenség, amit előre akar jelezni, egyáltalán, mik a gazdasági folyamatok, és azok mely része tekinthető műszaki kérdésnek és mely része szociológiai probléma. Teremt magának egy világot, és jobb lehetőség nem lévén, azt vizsgálja. Hangsúlyozom, hogy ez nem baj, sőt, ez a tudományos módszer, ez az egyedül járható út. Mindaddig, amíg ez kellő belátással, őszinteséggel és alázattal történik. Ahogy én látom, éppen ezek hiányoznak. Hiába, meg kell valahogy élni, ki kell fizetni a gyerek tandíját a méregdrága egyetemen, hiszen az a belépő a sikeres életbe. Kéz kezet mos. 
A valószínűségszámítás egy nagyon szép, elegáns matematikai elmélet, amely számos elvi buktatóval rendelkezik, de nincs nála jobb. Ha nagyon alaposan megnézzük, akkor az axiómák szintjén is láthatjuk, hogy egy alapvető kérdésre nem tud választ adni: nevezetesen, miként kell a metszet valószínüségét kiszámolni. A megkerülő megoldás, hogy bevezetjük a feltételes valószínűséget, de nem mondjuk meg, hogyan kell kiszámolni. Pontosabban, a bevezetett definíciót mindig fordítva kell használni. Ha ismerjük a feltételes valószínűséget, akkor azt a feltétel valószínűségével beszorozva megkapjuk a metszet valószínűségét. Eltekintve az elemi példáktól, soha nem tudjuk a feltételes valószínűséget meghatározni, nem beszélve arról, hogy nem is érdekel minket. Amit szeretnénk tudni, az a különböző események együttes bekövetkezésének valószínűsége, vagyis a különböző megfigyelt jelenségek egymáshoz való viszonya. Ha jobban tetszik, a különböző események együtt mozgását, korrelációját szeretnénk ismerni, ahol a korreláció szót most igen általános értelemben használom. A feltételes valószínüség az a pont, ahol a modellezendő jelenség tulajdonságait a valószínűségi modellbe becsempésszük. Például azt mondjuk, hogy az árfolyamok Markov-láncot alkotnak, vagy azt mondjuk, hogy a hozamok Lévy-folyamatot alkotnak. Minden modellezésnek ez a problémás lépése. Innentől már minden matematika. Ami persze nem jelenti azt, hogy a következtetés helyes, ugyanis miként a Poissonfolyamat kapcsán jeleztem, nem biztos például, hogy az eltérő időfogalmak miatt a számítások nem élesítik ki a hibákat. Mivel a két rendszer nem azonos, az egyik modell transzformációja a másik modell olyan oldalára mutathat rá, ami a kiinduló helyzetben még nem látszott. Vagyis a matematika nem feltétlenül a következtetést segíti, hanem a hibák feltárását. Ha lehet, a gazdasági folyamatok esetén mindenképpen ez a fontosabb szerep. A derivatív árazás elméletében a legfontosabb matematikai eredmény annak a bemutatása és föleg felismerése, hogy a piac teljessége az árazó formula levezetésében döntő szerepet játszik. Szemben a bevezető tankönyvekkel, nem az arbitrázsmentesség a döntő feltétel, hanem a teljesség. Ezt a matematikai vizsgálatok tárták fel. Ez a tudományos közösség hozzájárulása. Hasonlóképpen, az általános egyensúlyelmélet fö eredménye az, hogy rámutatott arra: csak konvex technológiák esetén lehet a kereslet és a kínálat egyensúlyáról beszélni. A tényleges gyakorlati használat hibái is többek között abból eredtek, hogy a különböző származtatott termékek valójában nem voltak lefedezve; miért is lettek volna, hiszen tökéletes fedezés csak a mesében, ha tetszik, csak a matematikában létezik.

Természetesen a különböző korok másképpen nézték a világot. Itt is egy nagyon nehéz kérdésre kell választ keresni. A 18. és a 19. század nagyon optimista volt. Miért is? Határozottan azt gondolták, hogy a világ megismerhető és megváltoztatható. Elegendő csak Beethovent hallgatni. Egyszerü, áttekinthető struktúra. Minden világos, minden tiszta, inkább minden kristálytiszta és gyönyörü. Ez az egyszerü- 
ség és nagyszerüség minden korban lenyügözi az embereket. Sajnos az optimista 19. század úgymond a Nagy Háború csatamezőin eltünt, és helyet adott a 20. századnak. A matematika oldaláról a 19. század nagyrészt a deriválhatóságról szólt. Az, hogy egy folyamat, egy függvény nem deriválható, fel sem merült. A deriválhatóság azonban előrejelezhetőséget jelent. Mivel a múltat ismerjük vagy ismerni véljük, tudjuk a balról vett deriváltat. Mivel a függvény deriválható, ezért tudjuk a jobb oldali deriváltat is, vagyis tudjuk, hogy mi fog a jövőben történni. Sőt, a függvények nemcsak deriválhatók, hanem úgymond ultraderiválhatók is. Függvényen ugyanis általában komplex deriválható függvényt értettek. A komplex deriválható függvények fontos tulajdonsága, hogy egy kicsi darabjukat megfigyelve, a teljes függvény egyértelműen megadható. Az egyszerüség kedvért kicsi darabon egy tetszőlegesen kis szakaszon való értéket értünk. Vagyis ha egy függvényt egy nagyon rövid szakaszon ismerünk, akkor teljesen, mindenkorra és mindenhol ismerni fogjuk. Teljes determinizmus. Hasonló gondolatmenet érvényes a differenciálegyenletek esetén. Ha ismerjük az induló feltételeket, akkor a rendszer örök törvényeit is ismerni tudjuk.

Persze, a matematika nagyjából ötven évvel jár mindig a világ elött. A megismerhető világ eszméje lassan foszlani kezdett. Egyre világosabbá vált, hogy a dolgok mégsem olyan egyszerüek. Különböző okokból, de egyre sokasodtak az ellenpéldák. A fö csapás a trigonometrikus sorok elmélete felől érkezett. Kiderült, hogy egyszerű hullámokból lehet szakadásos függvényt csinálni. Majd jött a végső csapás. Weierstrass, a modern analízis atyja 1872-ben egy olyan függvényt konstruált, amely ugyan folytonos volt, de egyetlen pontban sem volt deriválható. 1821-ben Cauchy, a kor legnagyobb matematikusa még be is látta, hogy egy folytonos függvény néhány speciális ponttól eltekintve deriválható. Fel szokás emlegetni, hogy Cauchy nem látta, nem vette észre a pontonkénti konvergencia és az egyenletes konvergencia közti eltérést. ${ }^{4}$ Miközben ez igaz, sokkal inkább igaz az is, hogy meg sem fordult a fejében: létezik olyan mozgásforma, amelyet legalább egy rövid ideig nem vagyunk képesek előre látni. Cauchy nem matematikai hibát követett el, hanem filozófiai hibát. Be akart valamit látni, ami nem volt igaz. Ha úgy tetszik, a vágyait a valóság fölé helyezte. Weierstrass ellenpéldája a tudománytörténetben fordulópont. Egyrészt világossá vált, hogy a szemlélet nem elegendő alapja a matematikának; a matematikának szigorú logikai alapra kell épülnie és axiomatikusnak kell lennie. Weierstrass előtt a szemléletes és az igaz azonos volt. Nemcsak azt gondolták, hogy a világ megismerhető, hanem azt is, hogy a világ egyszerü, és valóban, isten nem csupán kockákat nem dobál, hanem nem is gonosz, sőt büszke a teremtésre, és az emberek, felvértezve a

4 Bezzeg mi milyen okosak vagyunk, ezért simán megbuktatunk, teljes joggal, bárkit. 
mindentudás almájával, csodálhatják is a teremtést, és ezen keresztül a Teremtőt is. A matematika ezen a ponton elkezdett önálló utat járni, lényegében levált a fizikáról és tegyük hozzá, általában az alkalmazásoktól. A tudományterület célja megváltozott. Helyesen vagy helytelenül, az igaz fogalmát felcserélte a logikailag hibátlan fogalmára. A matematika törekvése, hogy a lehető leginkább megszabaduljon a szemlélettől, és a dolgok logikai szempontjait hangsúlyozza. Helyesen vagy helytelenül, de a szemléletet csak legfeljebb a megsejtés nagyon fontos segédeszközének tekinti. Bármennyire is szemléletes valami, ettől még nem lesz igaz, az összefüggést logikai úton le kell tudni vezetni az axiómákból. Ez megjelenik a matematikakönyvek nyomdai külalakjában is. Egy „jó” matematikakönyvben nincsenek ábrák. Szemben minden más tudományterülettel, így a közgazdaságtannal is, ahol egy jó ábra többet ér ezer szónál. Diractól állítólag megkérdezték, hogy mi a fizika és a matematika közti különbség. Dirac szerint mind a két tudomány egyenletekről szól, sőt ugyanazon egyenletekről. De egy fizikus anélkül is meg tudja mondani az egyenlet megoldását és a megoldás hozzávetőleges tulajdonságait, hogy azt megoldja. Egy matematikusnak meg kell oldania az egyenletet, és azt ki kell elemeznie ahhoz, hogy tudja a választ. Sőt tegyük hozzá, egy matematikus első gondolata, hogy belássa, van megoldás, az egyenlet és a példa, feladat nem tartalmaz belső ellentmondást.

Kolmogorov valószínűségszámítási elmélete tipikus példája ennek a törekvésnek. Egy axióma és definíciórendszer, amely a számolásokat korrektté és matematikailag kezelhetővé teszi. Ennek legfőbb eszköze, hogy a várható érték fogalmát az absztrakt Lebesgue-féle integrálkonstrukcióra alapozza. Vagyis a rendszer logikai stabilitása és könnyü használhatósága a cél. Ennek eszköze egy akkortájt még éppen hogy kialakult matematikai elmélet „interpretálása”. És ezek után természetesen briliáns matematikai tételeket bizonyított be, például a róla elnevezett nagy számok erős törvényét, evvel igazolva, hogy a javasolt axiómarendszer hatékony és működőképes. Kolmogorov elméletének azonban van egy gyenge pontja: a feltételes valószínűség kezelése. A feltételes valószínűséget mindenki egy igen szemléletes fogalomnak tekinti. A valószínűségszámítással ismerkedők legnagyobb meglepetésére ez távolról sincs így. Miként már jeleztem, a feltételes valószínüség bevezetésének célja az, hogy a metszet valószínűségét meg tudjuk határozni, és a feltételes valószínűség az a fogalom, ahol a „valóság” bevihető a modellbe. Ezek után éppen ezen a ponton egy sor technikai nehézség jelenik meg. Ez formailag úgy szokott jelentkezni, hogy vajon a feltételt mikor lehet bevinni az összefüggésbe, vagyis például az $X=x$ feltétel teljesülése esetén mikor lehet az $X$ valószínűségi változót az $x$ értékkel helyettesíteni. A probléma abból ered, hogy nem tudjuk megmondani, mi a feltételes valószínűség, ha a feltétel valószínűsége nulla. Általában a nulla valószínűségű halmazok az elméletben túlságosan is nagy szerepet játszanak. Például a sztochasztikus analízisben a vizsgálat kezdetén már meg kell 
állapodni abban, hogy mit fogunk nulla valószínüségü halmaznak tekinteni. Ha a nulla valószínüségü halmazokat azonosítjuk a lehetetlen eseményekkel, akkor már a vizsgálat elején meg kell mondani, hogy mely események lehetségesek és melyek nem. Ezek részben filozófiai szempontból, részben technikai matematikai oldalról komoly nehézségek forrásai, de sajnos, ilyen a rendszer, senki sem tudott ez idáig jobbat és ügyesebbet javasolni.

Weierstrass példája egyfajta szálka volt a tudomány körme alatt. ${ }^{5}$ A nagy fordulatot a Wiener-folyamat jelentette, amikor kiderült, hogy a hőmozgás, illetve Bachelier nem nagy figyelmet kiváltó kutatásai alapján a részvények árfolyamai nem deriválhatók. Vagyis a múltból nem tudunk a jövőre nézve semmit sem tanulni. Talán érdemes megjegyezni, hogy Louis Bachelier 1900-ban védte meg nem túl nagy érdeklődés mellett a dolgozatát, illetve Einstein a speciális relativitáselmélettel lényegében egy időben 1905-ben adta meg a Brown-mozgás magyarázatát, és evvel döntő bizonyítékot nyújtott az atomok létezésére.

A 18. és 19. század a bolygómozgások örök szabályaiból és a differenciálegyenletek determinizmusából próbálta a világot megérteni. Marx is azt gondolta, hogy a társadalmi kérdések az anyagi világ szabályai alapján megérthetők és a helyes irányba terelhetők. Micsoda tévedés! A 20. század eleje már a véletlenre építette a világképét. A Wiener-folyamat nemcsak egy matematikai bravúrkonstrukció, hanem egy más világfelfogás is. Mit tudunk mondani: maximum statisztikai mutatókat. Sőt, még azt se. A véletlen és a kiszámíthatatlanság uralja a világot. Legyünk őszinték, szinte bármely percben elveszthetjük a megtakarításainkat. A legbölcsebbek is csak azt tudják mondani, ne tegyük az összes tojást egy kosárba. Erről a devizahitelesek vagy a brókerbotrányok áldozatai sok regényes történetet tudnának mesélni. A középiskolás tananyagok fejlesztésekor érdemben felmerül, hogy a matematika és a fizika rovására pénzügyi ismereteket kellene tanítani. Természetesen nem mondom azt, hogy ez helytelen. Csak annyit mondok, igen, sajnos fel kell készíteni a diákokat a valós veszélyekre. Fel kell hívni a figyelmet arra: bármikor történhet egy olyan fordulat, hogy életük megtakarítása semmivé lesz. És ez fontosabb annál, mint hogy megértsék, miért kell föl a nap, és hogyan változik a hold.

5 Szőkefalvi-Nagy BÉla (1972): Valós függvények és függvénysorok. Budapest: Tankönyvkiadó, 15. o. A sokszor és sokak által idézett, nevezetes mondat, amely a kortársak reakcióját foglalja össze: „Rémülettel és borzalommal fordulok el ettöl a siralmas fekélytöl: függvények, amelyeknek nincsen deriváltjuk." Hangsúlyozni kell, hogy a heves reakció oka nem matematikai természetü volt, hanem a szemlélet és a matematika viszonya került drámaian új megvilágításba. 


\section{HIVATKOZÁSOK}

Feyman, R. P. - Leighton, R.B. - Sand, M. (1986): Mai fizika 5. (fordította: dr. Somogyi Antal). 3., javított kiadás. Budapest: Müszaki Könyvkiadó.

Medvegyev Péter (2014): Pénzügyi matematika. Budapest: Typotex.

SzÁz János: Valószínűség, esély, relatív súlyok. Opciók és reálopciók. Hitelintézeti Szemle 10(4), 336-348.

SzőKEFALVI-NAGY BÉLA (1972): Valós függvények és függvénysorok. Budapest: Tankönyvkiadó. 